\title{
Односи између латиноамеричких социјалистичких режима и Народне Републике Кине некад и сад
}

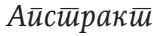

Народна Република Кина је још од 1950-их година у политичком и економском смислу присутна на простору Латинске Америке. Иако овај светски регион тада није важио за перспективан, с обзиром на ниске стопе привредног раста, недовољан степен индустријализације и ауторитарне политичке системе и културу, Кина је препознала његов потенцијал и кренула у постепено приближавање и отварање ка истом. Циљ овог рада је да испитамо квалитет политичких и економских односа између званичног Пекинга и латиноамеричких социјалистичких режима некада и сад како бисмо указали на значај идеолошког момента, односно марксистичко-лењинистичке политичке и економске матрице коју су обе стране делиле или је и даље деле. Полазна хипотеза рада јесте да је идеолошка блискост допринела лакшем приближавању два међусобно удаљена субјекта која се значајно разликују у погледу културе, религије и језика и која до тада нису имала значајније контакте током историје. Резултати истраживања показали су да је Кина од отварања ка свету крајем 1970-их до данас успела да направи незапамћен економски продор у готово све латиноамеричке државе и постане један од најзначајнијих трговинских партнера истих, али и да јача своју политичку позицију кроз активну дипломатију отпризнавања тзв. Републике Кине. У истраживању смо се користили историјском методом, компаративном методом, статистичком методом и методом студије случаја.
\end{abstract}

Кључне речи:

Кина, Латинска Америка, социјалистички режими, економија, политика, Тајван 


\section{УВОД}

Свега неколико година након завршетка Кинеске револуције 1949. године званични Пекинг је започео процес ширења свог политичког и економског утицаја широм света, па и на простору удаљене и за кинеску цивилизацију и културу недовољно познате Латинске Америке. Након завршетка Другог светског рата у Латинској Америци долази до све интензивнијег продора марксистичко-лењинистичке, односно комунистичке (у ширем смислу, са разним варијацијама) идеологије, што је битно утицало на динамику како унутрашњих политичких и економских односа у земљама овог региона тако и на спољнополитичке односе истих. Латиноамерички левичари организовали су се у различите покрете и политичке партије, али и милитантне организације са циљем освајања власти и спровођења комунистичке револуције у пракси. За латиноамеричке левичаре Народна Република Кина је, као земља под вођством Комунистичке партије још од 1949. године, увек имала посебно место из два разлога. Прво, комунистичка револуција у Кини, која је заправо била грађански рат у другој половини 1940-их, била је успешна, јер су комунистичке снаге Мао Цедунга (Máo Zédōng) поразиле националистичке снаге Куоминтанга под командом Чанга Кај Шека (Chiang Kai-shek), што је био важан подстрек и „рецепт за успех” комунистима широм света, па и оним у Латинској Америци. Друго, Кина је као комунистичка земља од 1949. године постала природни непријатељ Сједињеним Америчким Државама које су током Хладног рата изискивале огромне напоре да ограниче, а потом и сузбију присуство комунизма практично у свим деловима света. Односи Пекинга и Вашингтона све до данас остали су прилично затегнути због питања тзв. Републике Кине, односно тзв. Тајвана као независне државе коју Пекинг не признаје и сматра својом територијом. С обзиром на то да су сви латиноамерички левичари означавали САД као империјалистичку силу која је још доктрином бившег председника Џејмса Монроа (James Monroe) из 1823. године прогласила Латинску Америку својом интересном сфером (Betancourt Vélez, 2014, p. 691), званични Пекинг се наметнуо као природан савезник у борби против северноамеричке хегемоније на глобалном плану.

\section{ПОЧЕТАК ДУГОГ ПУТОВАЬА КИНЕ КА ЛАТИНСКОЈ АМЕРИЦИ}

Кина је на простору Латинске Америке присутна још од 1950-их година, када покушава да успостави прве економске везе са земљама попут 
Чилеа и Аргентине, али њено право присуство креће од 1960, када успоставља дипломатске везе са Кубом, у којој на власт 1959. године долази Комунистичка партија Кубе предвођена Фиделом Кастром (Fidel Castro). Ово ће се испоставити као један од пресудних момената на путу продора Кине ка социјалистичким латиноамеричким режимима, с обзиром на то да је на исте званична Хавана имала важан идеолошки и дипломатски утицај. Од 1970-их година Кина, као земља коју већина латиноамеричких држава још увек није ни признавала, креће у активну дипломатску мисију која је била заснована на четири основна принципа - миру, међусобној подршци, обостраној користи и развоју кроз партнерску сарадњу. С обзиром на јачање институција Уједињених нација и пораста значаја гласа сваке земље чланице, без обзира на величину и број становника, стратешки циљ Пекинга је било успешно спровођење „политике једне Кине” у Латинској Америци, односно признања Народне Републике Кине као „једине, истинске и легитимне” Кине и кочења или елиминисања дипломатских односа са Тајваном. Кина је на том пољу врло брзо остварила успехе, па је тако успоставила дипломатске односе са Аргентином и Мексиком 1972, Венецуелом и Бразилом 1974, те Боливијом 1985. године (Lafargue, 2006, p. 1).

\section{КИНА И ПЕРОНИСТИЧКА АРГЕНТИНА}

Иако је перонизам у Аргентини тријумфовао још 1940-их година, овај специфични социјалистички корпоративистички режим, који је покушавао да пронађе „трећи пут” између капитализма и комунизма, успоставља контакте са Кином тек средином 1970-их током председничког мандата Изабел Перон (Isabel Perón), друге супруге творца перонизма Хуана Перона (Juan Perón). Она је, у име Јустицијалистичке (перонистичке) партије, посетила централу Комунистичке партије Кине 1973. године (годину дана уочи председничких избора на којима је однела победу) и успоставила важне везе између две партије. Почетак интензивне економске и политичке сарадње две земље у пуном смислу чекао се, међутим, све до 2003. године, када на власт поново долазе перонисти предвођени Нестором Киршнером (Néstor Kirchner). Киршнер је остао упамћен као председник који је прекинуо односе између Међународног монетарног фонда и Аргентине, те у левичарском духу потражио партнере за сарадњу у „земљама слободног света”. Иако је генерал Хорхе Рафаел Видела (Jorge Rafael Videla) био први аргентински лидер који је отишао у званичну посету Пекингу још 1980. године, званична посе- 
та Нестора Киршнера Кини 2004. била је далеко више историјска. Током исте Киршнер је дефинисао „стратешко партнерство са Кином” и низом потписаних билатералних споразума различите врсте, отворио врата за повећање трговинске размене и инвестиција (Laufer, 2013, p. 127). У време власти Кристине Киршнер (Cristina Kirchner), од 2007. до 2015. године, Кина постаје један од три најзначајнија трговинска партнера Аргентини, где Аргентина у Кину највише извози соју и месо, а највише из ње увози индустријску опрему и различите савремене технологије. Посебно је важан податак да је Кристина Киршнер 2015. године потписала споразум са председником Кине Сиом Ђипингом (Xi Jinping) о сарадњи у области одбране и војне индустрије и ударила темеље за каснији споразум десничарске владе Маурисија Макрија (Mauricio Macri) са Пекингом о постављању кинеске станице за праћење сателита у Лас Лахасу у провинцији Неукен (Londoño, 2019).

\section{КИНА И КАСТРИСТИЧКА КУБА}

Као што смо претходно поменули, Куба је била прва латиноамеричка земља са којом је нова, комунистичка Кина успоставила дипломатске односе. Чињеница да је режим Фидела Кастра био прокламован као комунистички, те као такав под снажним економским, али и војним и дипломатским ударом САД, натерала га је да проналази геостратешке савезнике широм света, превасходно земље у којима је успостављен комунистички режим. Кина је свакако била једна од њих, али у почетним годинама хладноратовских превирања још увек недовољно снажна да буде изазивач званичном Вашингтону у правом смислу те речи. Управо зато се у периоду кинеско-совјетског раскола (1960-1989) Куба дистанцира од Кине и остаје чврст совјетски савезник. По окончању Хладног рата и распада Совјетског Савеза Куба почетком 1990-их улази у фазу успона политичких и економских односа са Кином. Захваљујући повећању обима трговинске размене, кинеским инвестицијама и позајмицама у милијардама америчких долара, Куба је релативно брзо постала други најзначајнији латиноамерички трговински партнер Кине (одмах иза Венецуеле). Куба већ три деценије може да рачуна на активну дипломатску подршку званичног Пекинга у међународним институцијама, а потврда значаја овог острва за Кину су и званичне посете њена два председника Хавани - Хуа Ђинтаa (Hú Jǐntāo) 2004. и Сиа Ђипинга 2014. године (Regalado Florido, 2018, pp. 69-77). 


\section{КИНА И ЧАВИСТИЧКА ВЕНЕЦУЕЛА}

До доласка на власт Уга Чавеза (Hugo Chávez) 1999. године Венецуела и Кина нису имале претерано значајне политичке или економске односе. Вредна помена је једино посета венецуеланског председника Луиса Ерере Кампинса (Luis Herrera Campins) Пекингу давне 1981. године, али која није донела значајније резултате, сем чињенице да су тиме две земље и дефинитивно потврдиле дипломатске односе успостављене седам година раније. Захваљујући идеолошкој блискости Пекинга и Каракаса, те изразитој антиимперијалистичкој и антивашингтонској политици чавистичког режима, од 1999. године све до данас односи две земље на готово свим пољима (економска улагања, трговинска размена, политичка сарадња, сарадња у међународним институцијама, војна и безбедносна сарадња) доживљавају вртоглави успон. Поред тога што је Венецуела постала најзначајнији кинески латиноамерички трговински партнер, она је, примера ради, била једна од ретких земаља које су подржале кинески Антисепаратистички закон из 2005. године усмерен против независности тзв. Републике Кине. Исто тако, Венецуела је чврсто подржавала кинеску политику према Ирану и Северној Кореји у периоду заоштравања међународних односа по овим питањима 2000-их и 2010-их година. Са друге стране, Кина је данас највећи кредитор Венецуеле (укупан венецуелански дуг према Пекингу износи око 23 милијарде долара) и једна од малобројних земаља које материјално, финансијски и дипломатски подржавају режим Николаса Мадура (Nicolás Maduro) који је већ годинама у кризи због низа санкција које трпи од стране САД и њихових савезника. Идеолошку блискост чавизма и кинеског комунизма најбоље је описао Уго Чавез речима које је изрекао (приликом једне од бројних посета Пекингу) на Пекиншком универзитету: „Боливарска револуција укорењена је у идеологији Мао Цедунга, творца комунистичке Кине” ... „Симон Боливар, ослободилац Венецуеле и доброг дела Латинске Америке, био је 'Цедунгова сродна душа'” (Dominguez, 2006, p. 44).

\section{КИНА И ЛУЛИСТИЧКИ БРАЗИЛ}

Бразил, као највећа латиноамеричка економија и земља у успону, посебно је значајан за Кину. Поред чињенице да су обе земље чланице БРИКС-а, и Кина и Бразил претендују да буду земље од глобалног значаја и утицаја. Баш као и у случају већине латиноамеричких земаља, и у 
Бразилу се све до доласка на власт левичарске Радничке партије, предвођене председником Инасијом Лулом да Силвом (Inácio Lula da Silva), није обраћала претерана пажња на сарадњу са Кином. Ствари се, међутим, битно мењају када је Лула дошао на власт 2003. године на „ружичастом таласу" који је запљуснуо бројне земље у региону. Две земље су најпре дефинисале потребу за сарадњом на обострану корист (тзв. win-win сарадња) и усагласиле се око поштовања принципа немешања у унутрашња питања, а затим су уследиле узајамне посете на највишем нивоу. Најпре је председник Кине Ху Ђинтао боравио у званичној посети Бразилији 2004. године, када је у бразилском Конгресу изрекао две важне поруке: да Латинска Америка и Кина имају слична искуства у борби за национално ослобођење, одбрану националне независности и изградњу државе, те да, у том смислу, обе стране имају иста осећања и говоре истим језиком, као и да кинеско-латиноамерички односи треба да подрже једни друге на пољу политике, јачања економије и да негују блиске културне односе (Shixue, 2007, pp. 76-102). Лула да Силва је, са друге стране, посетио Кину 2009. године заједно са 450 угледних бразилских привредника и том приликом је потписан низ билатералних споразума између две земље у областима привредне, економске и трговинске сарадње. Бразил је, захваљујући таквом интензитету сарадње, релативно брзо постао држава у коју Кина највише улаже у целој Јужној Америци, а Кина за званичну Бразилију стратешки партнер који највише обећава.

Не треба заборавити ни значајну сарадњу Кине са социјалистичким режимима мањих латиноамеричких земаља попут Боливије и Никарагве. Након доласка на власт Покрета ка социјализму у Боливији, предвођеног Евом Моралесом (Evo Morales) 2006. године, Боливија покреће све интензивнију сарадњу са Пекингом у области економије, инфраструктуре, саобраћаја, војној области (посебно значајан споразум потписан 2010. године када су две земље прослављале 25. годишњицу дипломатских односа), затим науке (Кина је финансијски помогла оснивање Боливијске свемирске станице која је 2014. године лансирала свој први сателит), али и пољопривреде, индустрије, енергетике и телекомуникација (Cерpi, 2014, pp. 138-139). Сарадња две земље на највишем нивоу дефинитивно је потврђена сусретом председника Сиа Ђипинга и Моралеса у Пекингу 2018. године, када су се обојица лидера сложила да су ти односи најбољи у историји. Повратком евиста на власт 2020. године блиске везе са Кином су обновљене, па је нови председник Боливије Луис Арсе (Luis Arce) у телефонском разговору са Сиом Ђипингом упутио захвалност Пекингу за помоћ у борби против Ковид-19 и истакао значај нераскидиве сарадње двеју пријатељских земаља коју треба зацементирати. Односи Никарагве и Кине су посебно интересантни. 
Шест година након доласка на власт левичарских сандиниста, предвођених Данијелом Ортегом (Daniel Ortega), званична Манагва 1985. године прекида односе са тзв. Републиком Кином, коју је признавао претходни десничарски режим Анастасија Сомозе (Anastasio Somoza), те успоставља дипломатске односе са званичним Пекингом. Десничари се враћају на власт 1990. године и поново прекидају односе са Пекингом, те признају тзв. Тајван. Помало неочекивано, након повратка на власт Данијела Ортеге 2007. године, односи са тзв. Тајваном нису прекинути. Ортега је то правдао никарагванском стратегијом „признања две Кине”, уз жељу да са обе земље гради пријатељство и економску сарадњу. Још парадоксалније делује чињеница да је Кина, упркос томе што нема амбасадора у Манагви, потписала 2014. године пројекат са Никарагвом о изградњи Никарагванског канала, грандиозног пројекта који би повезао Пацифик и Атлантик преко Никарагванског језера и који би био оштра конкуренција Панамском каналу под контролом САД. Иако пројекат још увек није реализован, нарастајућа моћ Кине иде у прилог томе да ће он у погодном тренутку бити ревитализован и као такав представљати симбол моћи пробуђеног азијског џина (Grau Vila, 2016, pp. 207-209).

\section{КИНЕСКО ЕКОНОМСКО И ПОЛИТИЧКО ПРИСУСТВО У ЛАТИНСКОЈ АМЕРИЦИ ДАНАС}

Кина данас на примеру свог политичког и економског присуства у Латинској Америци потврђује тезу да је реч о глобалној сили која је постала достојан изазивач САД. Од 2015. године Кина је главни трговински партнер Јужне Америке, појединачно гледано најважнији је трговински партнер Бразила, Перуа и Чилеа, а њено економско присуство има све већи значај и у Аргентини. Својим стратешким документом о Латинској Америци из 2008. године Кина је поручила владама земаља у овом региону да ће их „третирати као једнаке” и најавила озбиљна улагања у тамошњу инфраструктуру, развој технологија и помоћ за општи привредни опоравак и развој. Према подацима Економске комисије УН за Латинску Америку и Карипски басен, од 2005. до 2016. године Кина је инвестирала у Латинску Америку око 90 милијарди долара. У свом инвестиционом плану за период 2015-2025. године Кина је предвидела пораст вредности робне размене са Латинском Америком са 250 на 500 милијарди долара. Кинеске гигантске компаније попут „Дидија”, „ТЦЛ-а”, „Хуејин блокчејн вентура” и „Мобика” увелико су пронашле пут свог капитала до тржишта Мексика, Бразила, Аргентине или Чилеа (Спутњик, 
2019). Само током 2019. године Кина је инвестирала у Латинску Америку 12,8 милијарди долара. Данас Кина има споразуме о слободној трговини са Чилеом, Перуом и Костариком. У међувремену су обављени и преговори око споразума о слободној трговини са Панамом. Поред тога, 19 земаља Латинске Америке прикључило се пројекту „Пут свиле”, што само по себи сведочи о грандиозности овог стратешког пројекта и његовом глобалном карактеру. Јачање кинеског економског присуства у Латинској Америци значи, између осталог, и да је Кина изазвала свог геополитичког ривала САД на простору који се и даље сматра „америчким двориштем", односно њеном ексклузивном интересном зоном. Зато не чуди бес, али и страх званичног Вашингтона због незадрживог продора кинеског капитала у Латинску Америку. Томе се посебно оштро супротставила администрација Доналда Трампа (Donald Trump) која је била изразито синофобична. Тако је амерички државни секретар Мајк Помпео (Mike Pompeo) 2019. године оптужио Кину да шири неред по Латинској Америци и Карибима са својим директним инвестицијама које убризгава у тамошње привреде путем свог „корозивног капитала”, чиме подстиче локалну корупцију и ерозију добре владавине (Dussel Peters, 2019, pp. 1-6).

Економска моћ Кине у Латинској Америци се полако, али сигурно пројектује и на њену политичку моћ. Тако је Пекинг издејствовао да Панама, Доминиканска Република и Ел Салвадор прекину односе са тзв. Тајваном, што је важна дипломатска победа у овом делу света. Кина се, као што смо већ поменули, активно бори против америчких притисака на режим Николаса Мадура у Венецуели, помажући му на дипломатски и сваки други начин, а исто тако је традиционално блиска актуелним левичарским режимима у региону - перонистима у Аргентини, евистима у Боливији и неокастристима на Куби. Латинска Америка се, без икакве сумње, претвара у „бојно поље” између САД и Кине. Наравно, војних сукоба није било нити их је реално очекивати у блиској будућности, али су дипломатска и политичка надметања две силе увелико допунила она економска. Кина је данас посматрач у Организацији америчких држава, члан Интерамеричке развојне банке, члан Карипске развојне банке, те део Азијског пацифичког форума за сарадњу. Председник Си Ђипинг је јануара 2015. године окупио на самиту у Пекингу лидере и министре спољних послова држава чланица Заједнице латиноамеричких и карипских земаља, што је у САД дочекано са негодовањем. У сваком случају, кинеско присуство у Латинској Америци, иако у вртоглавом успону у погледу економије и дипломатије, и даље је ограничено због културолошке и језичке баријере и за сада су мале шансе да ће Кина, попут САД, бити и војно присутна у истој (Sullivan, 2021, pp. 1-3). 


\section{ЛИТЕРАТУРА}

1. Betancourt Vélez, R. (2014). ¿El ocaso de la Doctrina Monroe? Colombia y Brasil, entre el norte de siempre y un sur renovado. Papel Político, 19 (2), 691-719.

2. Ceppi, N. (2014). La política exterior de Bolivia en tiempos de Evo Morales Ayma. Si Somos Americanos. Revista de Estudios Transfronterizos, 14 (1), 125-151.

3. Dominguez, J. (2006). China's Relations With Latin America: Shared Gains, Asymmetric Hopes. Inter-American Dialogue, China Working Paper, June 2006, $1-59$.

4. Dussel Peters, E. (2019). China's Recent Engagement in Latin America and the Caribbean: Current Conditions and Challenges. The Carter Center, August 29, 2019, 1-12.

5. Lafargue, F. (2006). China's Presence in Latin America Strategies, Aims and Limits. China Perspectives, 68 (November-December 2006), 1-15.

6. Laufer, R. (2013). Argentina-China: New Courses for an Old Dependency. Latin American Policy, 4 (1), 123-143.

7. Londoño, E. (2019). From a Space Station in Argentina, China Expands Its Reach in Latin America. The New York Times, July 28; https://www.nytimes. com/2018/07/28/world/americas/china-latin-america.html (09.09.2021).

8. Regalado Florido, E. (2018). Las relaciones entre Cuba y la República Popular China. Revista Cubana de Economía Internacional, 2 (2018), 69-77.

9. Shixue, J. (2007). On the Development of Sino-Latin American Relations. China International Studies, 9 (Winter 2007), 76-102.

10. Sullivan, M. P. (2021). China's Engagement with Latin America and the Caribbean. In Focus, July 1, 2021, 1-3.

11. Сйуйюик (2019). Кина улаже милијарде у развој Латинске Америке, 13.01.2019; https://rs.sputniknews.com/20190113/Kina-latinska-Amerikaulaganje-1118481158.html (09.09.2021). 


\title{
Rajko Petrovic
}

\section{RELATIONS BETWEEN LATIN AMERICAN SOCIALIST REGIMES AND THE PEOPLE'S REPUBLIC OF CHINA THEN AND NOW}

\begin{abstract}
The People's Republic of China has been present in Latin America in the political and economic sense since the 1950s. Although this world region was not considered promising at the time, given the low rates of economic growth, insufficient degree of industrialization and authoritarian political systems and culture, China recognized its potential and started to gradually approach and open to it. The aim of this paper is to examine the quality of political and economic relations between official Beijing and Latin American socialist regimes then and now in order to point out the importance of the ideological moment, that is the Marxist-Leninist political and economic matrix shared or still shared. The initial hypothesis of the paper is that the ideological closeness contributed to the easier rapprochement of two mutually distant subjects who differ significantly in terms of culture, religion and language and who have not had significant contacts throughout history. The results of the research showed that from its opening to the world in the late 1970s until today, China has managed to make an unprecedented economic breakthrough in almost all Latin American countries and become one of their most important trading partners, but also to strengthen its political position through active diplomacy against the recognition of the so-called Republic of China. In the research, we used the historical method, the comparative method, the statistical method and the case study method.
\end{abstract}

Keywords:

China, Latin America, socialist regimes, economy, politics, Taiwan. 